\title{
Agnieszka Świętosławska
}

Katedra Historii Sztuki

Uniwersytet Łódzki

http://dx.doi.org/10.18778/2084-851X.05.16

\section{"Co znajduje się na obrazach Henryka Siemiradzkiego".}

\section{Konferencja naukowa, Warszawa 21-22 kwietnia 2017 r.}

Henryk Siemiradzki, jeden z najbardziej znanych reprezentantów nurtu kosmopolitycznego akademizmu drugiej połowy XIX wieku, międzynarodową sławę zdobył scenami antycznymi i biblijnymi. Współcześni cenili w nich nie tylko ładunek emocjonalny i techniczną wirtuozerię, lecz również wierne odtworzenie realiów starożytnego świata. Próba weryfikacji tych sądów stanowiła przewodni wątek konferencji "Co znajduje się na obrazach Henryka Siemiradzkiego", zorganizowanej w dniach 21 i 22 kwietnia 2017 roku przez Polski Instytut Studiów nad Sztuką Świata i Muzeum Narodowe w Warszawie. Spotkanie poświęcone było problematyce relacji sztuki Siemiradzkiego z dorobkiem sztuki greckiej, rzymskiej czy bliskowschodniej.

Warszawska konferencja była jednym z wydarzeń towarzyszących pięcioletniemu projektowi „Korpus dzieł malarskich Henryka Siemiradzkiego”, finansowanemu przez Ministra Nauki i Szkolnictwa Wyższego w ramach „Narodowego Programu Rozwoju Humanistyki”. W realizacji projektu bierze udział Polski Instytut Studiów nad Sztuką Świata oraz Muzea Narodowe w Krakowie i Warszawie przy współpracy zagranicznych instytucji naukowo-badawczych (Państwowa Galeria Tretiakowska i Państwowy Instytut Historii Sztuki w Moskwie, PontificioIstituto di StudiEcclesiastici w Rzymie). Z tego względu nie dziwi fakt, iż konferencja posiadała charakter międzynarodowy, a obok badaczy z Polski, zaproszeni do udziału zostali również przedstawiciele ośrodków rosyjskich i białoruskich. W spotkaniu uczestniczyli zarówno historycy sztuki, jak i archeolodzy, przedstawiciele środowisk akademickich, jak również muzealnicy na co dzień opiekujący się zbiorami dzieł artysty. Takie interdyscyplinarne podejście zapewniło różnorodność podejmowanych problemów badawczych oraz zastosowanych metodologii. To z kolei skutkowało podjęciem w ramach obrad wielu aspektów twórczości malarskiej Siemiradzkiego.

Założeniem organizatorów było skupienie badawczej uwagi na analizie twórczości Siemiradzkiego pod kątem inspiracji jego dzieł sztuką grecką, etruską, rzymską, egipską czy dalekowschodnią. Zagadnienie to znalazło już wyraz we wcześniejszych pracach poświęconych twórczości artysty. Dotychczas jednak fakt odtwarzania dzieł architektury, rzeźby, rzemiosła artystycznego, przedmiotów codziennego użytku bywał raczej konstatowany (i to w odniesieniu do najsłynniejszych prac malarza), niż 


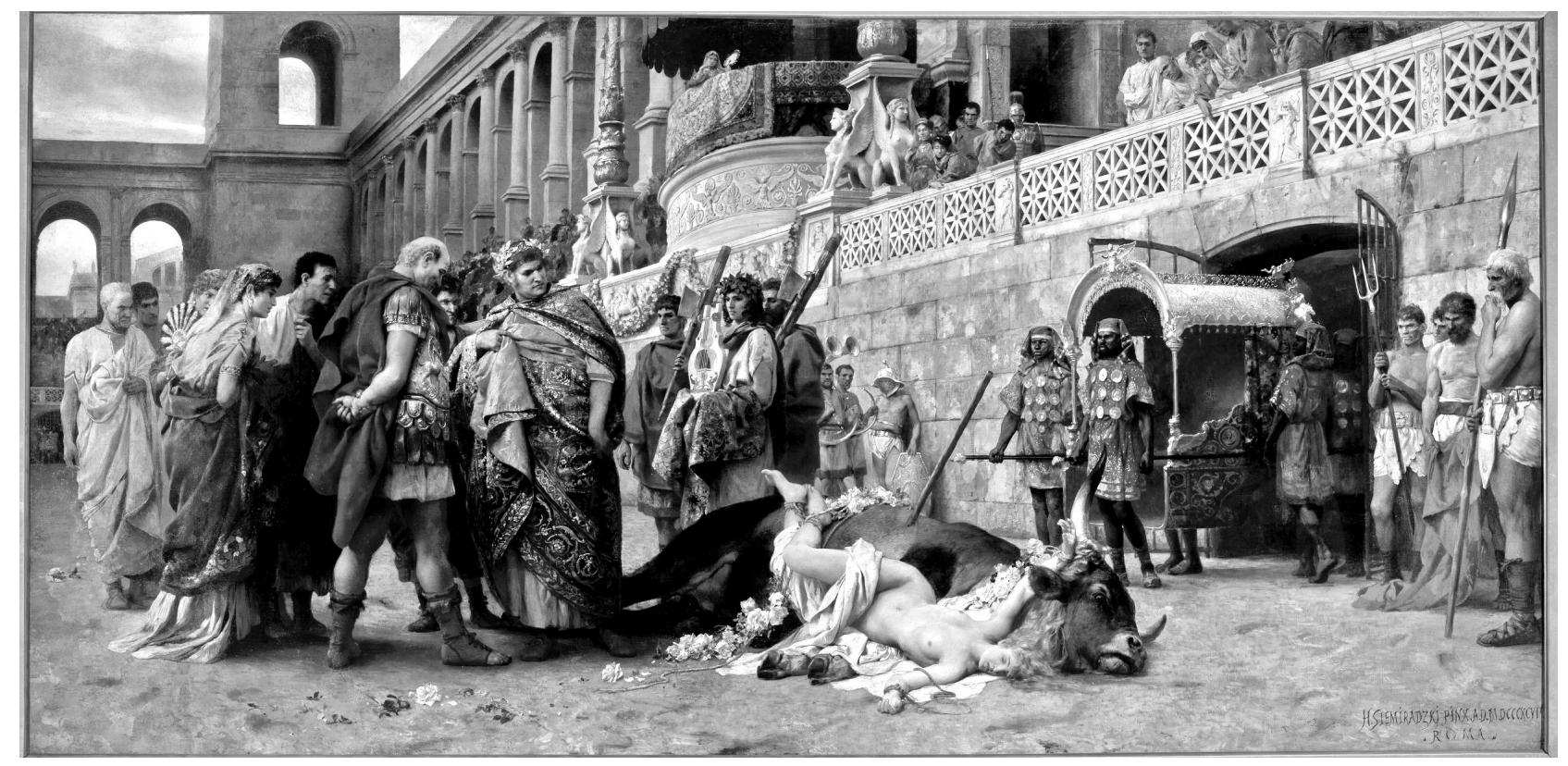

Henryk Siemiradzki,

Dirce chrześcijańska, 1897, Muzeum Narodowe w Warszawie poddany dogłębnej interpretacji w kontekście całego jego dorobku twórczego. Konferencja stała się okazją do wymiany spostrzeżeń dotyczących zakresu wpływu kultury klasycznej na artystę na przestrzeni całego jego życia. Z jednej strony skupiono się na czasach jego studiów na petersburskiej uczelni, gdzie antykizująca tematyka wynikała z podjęcia obowiązujących konwencji sztuki akademickiej. Nawet ważniejszym obszarem rozważań stał się jednak dojrzały okres twórczości, związany z pobytem w Rzymie, kiedy artysta miał dostęp nie tylko do zbiorów dawnych artefaktów, lecz również do najnowszych naukowych opracowań poświęconych kulturze materialnej interesującego go okresu. Podjęte przez prelegentów analizy takich dzieł jak praca dyplomowa z czasów studenckich "Zaufanie Aleksandra Macedońskiego do lekarza Filipa”, monumentalne „Pochodnie Nerona” (w 1879 roku ofiarowane przez autora miastu Kraków jako zaczątek zbiorów Muzeum Narodowego) czy „Dirce chrześcijańska”, która powstała w ostatnich latach działalności malarza, wykazały przemianę postawy twórcy i jego wizji starożytności. Ewoluowała ona od konwencjonalnego użycia idealizowanego kostiumu rzymskiego po motywowaną znawstwem rekonstrukcję opartą o aktualny stan wiedzy historyczno-archeologicznej.

Podczas konferencji obok wątku związanego z ikonograficznymi, ale też ideologicznymi zależnościami obrazów Siemiradzkiego od dziedzictwa starożytności, wyraźnie zaznaczył się także drugi nurt badań nad dorobkiem artysty, reprezentowany mniej może licznie, ale interesujący - bo rzadko będący przedmiotem refleksji badawczej. Przedmiotem rozważań stały się zagadnienia związane z warsztatem 
pracy artysty, nie tylko w wąskim rozumieniu aspektów technologicznych i stosowanych rozwiązań artystycznych, lecz także w szerszym ujęciu funkcjonowania malarza w życiu artystycznym epoki. Podjęta została problematyka kształtowania się światopoglądu i formacji intelektualnej malarza, wpływu oczekiwań współczesnych odbiorców czy roli fotografii tak w powstawaniu obrazów, jak również w ich popularyzacji poprzez reprodukcje.

Konferencja, co podkreślali uczestnicy debaty, potwierdziła iż kluczową rolę w dorobku Siemiradzkiego odgrywają sceny z motywami antycznymi i wczesnochrześcijańskimi. Podsumowano także dotychczasowy stan badań i wskazano obszary tego zagadnienia wymagające dalszej eksploracji, co równocześnie przyczyniło się do dostrzeżenia nowych kwestii, dotychczas niepodejmowanych przez znawców jego sztuki. Niespodziewanie jednym z głównych obszarów zainteresowania stała się nie tyle relacja sztuki Siemiradzkiego z dziedzictwem antyku, lecz jego związki z akademizmem oraz innymi nurtami kulturowo-artystycznymi epoki. Powracającym zagadnieniem było pytanie czy wypracowana przez Siemiradzkiego formuła malarstwa historyczno-rodzajowego powinna być postrzegana jako ostateczne wypełnienie reguł doktryny akademickiej, wpojonej twórcy w czasie studiów w Petersburgu, czy też jako ich twórcze przekroczenie. Tym samym warszawska konferencja otworzyła nowe perspektywy badań jego twórczości w kontekście rozwoju nowoczesnych tendencji artystycznych w malarstwie polskim, ale i europejskim, drugiej połowy XIX wieku. 